\title{
EFFECT OF THE TREHALOSE LEVELS ON THE SCREENING OF YEAST AS PROBIOTIC BY IN VIVO AND IN VITRO ASSAYS
}

\author{
Flaviano S. Martins ${ }^{1,2,3}$; Ieso C. Miranda ${ }^{4}$; Carlos A. Rosa ${ }^{2}$; Jacques R. Nicoli ${ }^{2}$ and Maria J. Neves ${ }^{1 *}$ \\ ${ }^{1}$ Centro de Desenvolvimento da Tecnologia Nuclear/Comissão Nacional da Energia Nuclear, Belo Horizonte, MG, Brasil; \\ ${ }^{2}$ Departamento de Microbiologia, Instituto de Ciências Biológicas, Universidade Federal de Minas Gerais, Belo Horizonte, MG, \\ Brasil; ${ }^{3}$ Faculdade de Medicina, Universidade Federal de Minas Gerais, Belo Horizonte, MG, Brasil; ${ }^{4}$ Escola de Farmácia, \\ Instituto de Ciências Exatas e Biológicas, Universidade Federal de Ouro Preto, Ouro Preto, MG, Brasil.
}

Submitted: August 07, 2007; Returned to authors for corrections: November 04, 2007; Approved: January 21, 2008.

\begin{abstract}
Probiotics are viable defined microorganisms (bacteria or yeasts) that exert a beneficial effect on the health of the host when ingested in adequate amounts. Screening for such biotherapeutic agents is commonly performed by in vitro assays simulating gastrointestinal environment to determine the ability to survive in the digestive tract. In the present study, the possibility of extrapolation of data obtained in in vitro assays to in vivo conditions was studied using five Saccharomyces cerevisiae strains isolated from Brazilian Atlantic rain forest. Trehalose contents and survival after exposure to a combination of physiological stresses generally found in the gastrointestinal tract of humans were determined for the five yeasts and compared to the behavior of Saccharomyces boulardii, a well-known probiotic. The results were completed with the colonization capacity of the gastrointestinal tract of gnotobiotic mice by these yeast strains. Some results obtained by in vitro assays are not confirmed by in vivo experiments, indicating that the extrapolation cannot be always done.
\end{abstract}

Key words: Probiotic, Saccharomyces boulardii, Saccharomyces cerevisiae, stress, trehalose.

\section{INTRODUCTION}

Due to the increase in antibiotic resistance, there is a conscious research to found new treatments with minimal secondary effects, mainly for enteropathogenic infections, "through increasing immunization coverage with existing vaccines, and through the development of newer, more effective and safer vaccines. In addition, several older forms of therapy, including bacterial interference, serum therapy and the use of macrophages to kill organisms, may be worth reconsidering" (4). In this way, probiotics have been suggested as one of the possible alternatives. Probiotics are commonly considered as viable defined microorganisms (bacteria or yeasts) that exert a beneficial effect on the health of the host when ingested in adequate amounts (5). These microorganisms are widely used in pharmaceutical preparations or fermented dairy products (10). In addition to their nutritive value, yeasts appear to provide beneficial modulation of disturbances of the gastrointestinal ecosystem (1) and among them, Saccharomyces boulardii may be regarded as the most used and studied probiotic $(8,16)$.

Theoretically, any non-pathogenic bacteria, fungi, yeasts or protozoan are possible candidate for probiotic use. However, the number and the diversity of these microorganisms make the screening of biotherapeutic agents among them a very hard task. A simple and efficient method for this selection is needed to process a very high number of microorganisms. In vivo assays are time consuming and involve a large quantity of animal groups and for these reasons are used only after the selection of a limited number of probiotic candidates. One procedure generally described in literature concerned is the in vitro screening based on the capacity of a microorganism to survive in the simulated

*Corresponding Author. Mailing address: Laboratório de Radiobiologia, CDTN/CNEN, C.P. 941, 30123-970, Belo Horizonte, MG, Brazil. Tel.: +55 (31) 3069-3177. E-mail: nevesmj@cdtn.br 
conditions of the digestive tract since this is indispensable for a probiotic to act.

The microorganism used as probiotic must confront a variety of simultaneous or sequential adverse conditions such as mild heat shock (internal body temperature), acidic gastric juice, basic pancreatic juice and the presence of lysozyme and bile salts (10). This problem is particularly important when the probiotics are not originally from the digestive tract of mammals, as is the case for Saccharomyces strains. In this context, in vitro selection of probiotic microorganisms is done by the exposure of microbial candidates to conditions simulating the gastrointestinal conditions and determination of its survival. All microorganisms have the capacity of detect changes in environments and to cope with the deleterious effects of this alteration with rapid molecular responses to repair damage and protect themselves against further exposure to stress. One of the best-characterized responses involves the synthesis of trehalose. Intracellular accumulation of trehalose has been associated with increased thermotolerance of bacterial, yeast, and fungal cells (21). Besides heat, other stress conditions such as $\mathrm{CuSO}_{4}, \mathrm{H}_{2} \mathrm{O}_{2}$ or ethanol concentrations and dehydration can also induce trehalose synthesis $(3,9)$. Since in most cases a close correlation between trehalose has been associated with increased tolerance of bacterial, yeast and fungal cells (21), the screening of yeast strains were starting using the capacity of yeast cells to accumulate trehalose. However, it is not very clear if results obtained in in vitro experiments can be always extrapolated to in vivo environment.

In the present study, the correlation between in vitro and in vivo assays used for the selection of possible probiotic yeast was studied.

\section{MATERIALS AND METHODS}

\section{Yeast strains and culture conditions}

Five yeast strains were isolated from different microhabitats in the Atlantic rain forest of South East Brazil (Table 1). The strains were all identified as Saccharomyces cerevisiae by standard methods (11). Saccharomyces boulardii was obtained from Merck S.A. (Floratil ${ }^{\circledR}$, Rio de Janeiro, RJ, Brazil). Cells were routinely grown in YPG medium (1\% yeast extract, $2 \%$ bactopeptone, $2 \%$ glucose) incubated at $30^{\circ} \mathrm{C}$ with agitation at $150 \mathrm{rpm}$.

\section{Mice}

Germ-free 21-days-old NIH mice (Taconic, Germantown, NY, USA) of both sexes were used in this study. Germ-free animals were housed in flexible plastic isolators (Standard Safety Company, McHenry, IL, USA) and handled according to established procedures. Experiments with gnotobiotic mice were carried out in microisolators (UNO Roestvastaal B.V., Zevenar, The Netherlands). Water and commercial autoclavable diet
(Nuvital, Curitiba, PR, Brazil) were sterilized by steam and administered ad libitum to the animals. Controlled lighting (12 $\mathrm{h}$ light, $12 \mathrm{~h}$ dark) was used for all the animals. All experimental procedures were carried out according to the standards set forth in the "Guide for the Care and Use of Laboratory Animals" of the National Research Council (18).

\section{Heat shock}

Cultures harvested in exponential phase (confirmed by the glucose levels presented on liquid medium) were divided into two aliquots. One was maintained at $30^{\circ} \mathrm{C}$ (control) and the other exposed to mild heat shock at $37^{\circ} \mathrm{C}$. The incubation time varied depending on the experiment and when longer than $1 \mathrm{~h}, 2 \%$ glucose was added to ensure that cells remained in the exponential phase.

\section{Gastric and pancreatic juice stresses}

Cells harvested in exponential phase were submitted to simulated gastric and pancreatic juices according to Charteris et al. (7). Juices were prepared with pepsin $\left(3.0 \mathrm{~g} \mathrm{l}^{-1}\right)$ or pancreatin $\left(1.0 \mathrm{~g}^{-1}\right)$ in saline $(0.5 \%, \mathrm{w} / \mathrm{v})$, the $\mathrm{pH}$ being adjusted, respectively, to 2.0 or 8.0 with $1 \mathrm{M} \mathrm{HCl}$ or $0.1 \mathrm{M} \mathrm{NaOH}$ before $2 \%$ glucose was added to each preparation. Control cells were incubated in YPG medium. Combinations of experiments were performed at $30^{\circ} \mathrm{C}$ and $37^{\circ} \mathrm{C}$.

\section{Bile salts stress}

Cultures harvested in exponential phase were transferred to YPG medium supplemented with a mixture of $0.2 \%$ bile salts, containing approximately $50 \%$ sodium cholate and $50 \%$ sodium deoxycholate (Sigma Chemical Co., St. Louis, MO, USA) and incubated during $60 \mathrm{~min}$ at $30^{\circ} \mathrm{C}$ or $37^{\circ} \mathrm{C}$.

\section{Determination of trehalose contents}

At the end of the experimental period, samples were harvested by vacuum filtration and the cell pellets were scraped off the membranes and immediately frozen in liquid nitrogen. The pellets were stored at $-20^{\circ} \mathrm{C}$ and used to determine trehalose content as previously described (19).

\section{Determination of survival}

At the end of the experimental procedure, cell suspensions were appropriately diluted and spread onto plates containing YPG agar medium. Cell viability was measured by colony forming units (cfu) counts after incubation at $30^{\circ} \mathrm{C}$ during $2-3$ days. The survival fraction was calculated separately for each sample as a percentage relative to survival of unstressed control samples. Results were expressed as the means of two viability values with a standard deviation $<9.5 \%$.

\section{Animal treatments}

A single dose of $10^{8}$ viable cells of each $S$. cerevisiae strain was administered to germ-free mice (five animals/group) by 
intragastric intubation. During 10 days freshly feces were collected, diluted 100 fold in saline and vortexed. Serial 10 fold dilutions were made and $0.1 \mathrm{ml}$ plated onto Sabouraud Dextrose agar (Difco, Sparks, MD, USA) and incubated at $37^{\circ} \mathrm{C}$. The colony unit counts were determined after 2-3 days.

\section{Statistical analysis}

Trehalose contents were calculated from the mean of a minimum of three or nine independent experiments for stress or control conditions, respectively, and analyzed for statistical significance by two-tailed Student's t-test, using the Epistat computer program (T.L. Gustafson, Round Rock, TX, USA). The significance level was set at $p<0.05$.

\section{RESULTS AND DISCUSSION}

Table 1 shows the influence of simulated gastric environment (independent or simultaneous exposures to mild heat shock and/or strong acidic conditions) on the trehalose contents and survival of the $S$. cerevisiae isolates tested as well as of $S$. boulardii. Basal trehalose contents (YPG, $30^{\circ} \mathrm{C}$ ) were higher in the yeast isolates (ranging from $0.74 \pm 0.48$ to $5.03 \pm 2.92 \mu$ moles glucose $\mathrm{g}^{-1}$ wet weight) when compared to $S$. boulardii $(0.20 \pm$ $0.18 \mu$ moles glucose $\mathrm{g}^{-1}$ wet weight). Both mild heat and acidic treatments induced the accumulation of high trehalose levels in all the strains. This effect is more pronounced after heat exposure, excepted for UFMG 24. Relatively, the induced accumulation of trehalose contents was higher in $S$. boulardii (28.1 and 63.3-fold increase in response to acidic and mild heat shock, respectively) than in yeast isolates (3.8- to 10.9-fold increase for acidic stress and 4.6 to 21.3-fold for mild heat shock). A higher synergistic effect on trehalose accumulations was also observed for S. boulardii (92.0-fold) when yeast cells were exposed simultaneously to mild heat and acidic stresses than $S$. cerevisiae isolates (7.7 to 20.2-fold). The UFMG 21 and 23 strains presented lower trehalose contents in all situations when compared with the other isolates, as well as a lower survival rate. However, even with similar trehalose levels, $S$. boulardii showed a good survival rate under the different conditions of stress. Overall, there was no direct correlation between the absolute levels of trehalose in the stressed cells and their viability.

The presence of $2.0 \mathrm{mg} \mathrm{ml}^{-1}$ of bile salts induced a relative increase in trehalose contents only for $S$. boulardii and $S$. cerevisiae UFMG 20 and 21 (Table 2) and the values observed were lower than those obtained in response to acidic and/or mild heat stresses. Exposure to bile salts constituted a highly aggressive stress for $S$. boulardii, since all the cells died after 1 $\mathrm{h}$ of this treatment. The other strains were more resistant to this condition and at $30^{\circ} \mathrm{C}$ the presence of bile salts was responsible for no more than $25 \%$ mortality. The simultaneous exposure to bile salts and mild heat stresses led to higher relative increases in trehalose contents of all the yeasts tested, except for $S$. cerevisiae UFMG 20. This stress combination was more deleterious only for $S$. cerevisiae UFMG 24, the survival of this strain falling to $25 \%$. In yeasts exposed to bile salts and/or mild heat stress, there was again no direct correlation between absolute levels or relative increase in trehalose content of the stressed cells and their viability.

The incubation of yeast cells in the presence of a simulated pancreatic juice increased the intracellular trehalose contents of all the strains tested (Table 3). As for gastric simulation, $S$. boulardii showed the highest relative increase (94.1- or 160.2fold, respectively, for pancreatic juice stress alone or in combination with mild heat shock). Overall, pancreatic juice simulation seemed to be the most deleterious condition for all

Table 1. Baseline trehalose levels and effect of simulated gastric conditions (exposure to acidic and mild heat stresses, singly or simultaneously) on trehalose accumulation and survival of isolates of $S$. cerevisiae strains and S. boulardii.

\begin{tabular}{|c|c|c|c|c|c|}
\hline \multirow[t]{2}{*}{ Strain } & \multirow[t]{2}{*}{ Micro-habitat } & \multirow{2}{*}{$\begin{array}{l}\text { Baseline trehalose } \\
\text { ( } \mu \text { moles glucose } \mathrm{g}^{-1} \text { wet } \\
\text { weight) contents }{ }^{1} /(\%)\end{array}$} & \multicolumn{3}{|c|}{$\begin{array}{l}\text { Alteration of trehalose content induced by stress } \\
\text { (x fold in relation to baseline contents) / Survival }(\%)\end{array}$} \\
\hline & & & Gastric juice $^{2}$ & Mild heat ${ }^{3}$ & Gastric juice + mild heat ${ }^{4}$ \\
\hline UFMG 20 & Drosophila $^{\mathrm{b}}$ & $2.11 \pm 1.12 / 100$ & $10.9 * / 70$ & $12.4 * / 70$ & $18.7 * / 59$ \\
\hline UFMG 21 & Drosophila & $0.74 \pm 0.48 / 100$ & $6.8 * / 51$ & $21.3 * / 76$ & $15.4 * * / 31$ \\
\hline UFMG 24 & Estuary & $5.03 \pm 2.92 / 100$ & $4.5 * / 112$ & $4.6 * / 99$ & $7.7 * * * / 81$ \\
\hline
\end{tabular}

${ }^{1}$ YPG, $30^{\circ} \mathrm{C} .{ }^{2} \mathrm{Pepsin} 3.0 \mathrm{~g} \mathrm{l}^{-1}, 30^{\circ} \mathrm{C}, \mathrm{pH} 2.0,2.0 \%$ glucose. ${ }^{3} \mathrm{YPG}, 37^{\circ} \mathrm{C} .{ }^{4} \mathrm{Pepsin} 3.0 \mathrm{~g} \mathrm{l}^{-1}, 37^{\circ} \mathrm{C}, \mathrm{pH} 2.0,2.0 \%$ glucose. ${ }^{\mathrm{a}} \mathrm{MERCK}$ S/A Pharmaceutical Industries, Rio de Janeiro, RJ, Brazil. ${ }^{b}$ Isolated from Tropical Forest, Brazil. ' Isolated from Tijuca Forest, Brazil. ${ }^{\mathrm{d}}$ Isolated from a small tropical fruit from Atlantic Rain Forest, RJ, Brazil. 'Isolated from estuary in Rio de Janeiro, RJ, Brazil. *Significant difference from baseline levels. $* *$ Significant difference from acidic stress levels alone. ***Significant difference from mild heat stress levels alone. 
Table 2. Baseline trehalose contents and effect of bile salts exposure and mild heat stress, singly or simultaneously, on trehalose accumulation and survival of isolates of $S$. cerevisiae and S. boulardii.

\begin{tabular}{|c|c|c|c|}
\hline \multirow[t]{2}{*}{ Strain } & \multirow[t]{2}{*}{$\begin{array}{l}\text { Baseline trehalose } \\
(\mu \text { moles glucose } \\
\mathrm{g}^{-1} \text { wet weight) } \\
\text { contents }^{1} /(\%)\end{array}$} & \multicolumn{2}{|c|}{$\begin{array}{c}\text { Alteration of trehalose } \\
\text { content induced by stress } \\
\text { (x fold in relation to baseline } \\
\text { contents) / Survival }(\%)\end{array}$} \\
\hline & & Bile salts ${ }^{2}$ & $\begin{array}{l}\text { Bile salts }+ \\
\text { mild heat }^{3}\end{array}$ \\
\hline S. boulardii & $0.20 \pm 0.18 / 100$ & $2.25 / 1$ & $4.4 * * / 0$ \\
\hline UFMG 20 & $2.11 \pm 1.12 / 100$ & $5.3^{*} / 128$ & $5.9 * / 85$ \\
\hline UFMG 21 & $0.74 \pm 0.48 / 100$ & $6.9 * / 110$ & $28.7 * * / 63$ \\
\hline UFMG 22 & $1.96 \pm 1.14 / 100$ & $-1.3 / 85$ & $14.6^{* *} / 68$ \\
\hline UFMG 23 & $0.95 \pm 0.85 / 100$ & $-1.7 / 91$ & $11.6 * * / 60$ \\
\hline UFMG 24 & $5.03 \pm 2.92 / 100$ & $-1.2 / 95$ & $3.2 * * / 21$ \\
\hline
\end{tabular}

${ }^{1} \mathrm{YPG}, 30^{\circ} \mathrm{C} .{ }^{2} \mathrm{YPG}, 30^{\circ} \mathrm{C}, 2.0 \mathrm{mg} \mathrm{ml}^{-1}$ bile salts. ${ }^{3} \mathrm{YPG}, 37^{\circ} \mathrm{C}, 2.0 \mathrm{mg} \mathrm{ml}^{-1}$ bile salts. *Significant difference from baseline levels. ${ }^{*}$ Significant difference from bile salts stress levels alone.

the yeasts tested, with survival rates ranging from $36-53 \%$. Simultaneous mild heat and pancreatic juice stresses significantly increased trehalose content only for $S$. cerevisiae UFMG 21 and 23 when compared to pancreatic juice alone, but without any marked change in survival rate.

Table 4 shows the yeast counts $\left(\log \mathrm{cfu} \mathrm{g}^{-1}\right)$ during ten days in the feces of gnotobiotic mice after a single intragastric inoculum of $10^{8}$ cells. The $S$. boulardii strain presented the higher number in the first day, but this number decrease in the period studied. The strains UFMG 21, 23 and 24 showed a good colonization. The strain UFMG 21 presented more stable count, during these 10 days when compared with the strains UFMG 23 and 24 . The strains UFMG 20 and 22 were not able to colonize the gastrointestinal tract of gnotobiotic mice.

In vitro studies have been used to evaluate various properties of microorganisms as criteria for the selection of potential probiotics. Among these, tolerance to mammal body temperature, low gastric $\mathrm{pH}$, bile salts and intestinal juices seem to be very important for survival (10) since they represent the first physicochemical barriers to microorganisms entering in the digestive tract.

Very few types of yeast have been studied as possible biotherapeutic agents and $S$. boulardii is one of the first and currently the only one employed in human medicine. Both animal studies and in vitro assays have shown that $S$. boulardii may have a protective effect and specific activities against various enteric pathogens $(6,20)$. Controlled clinical trials in humans have also shown the therapeutic properties of $S$. boulardii in patients,
Table 3. Baseline trehalose contents and effect of simulated pancreatic juice and mild heat stress, singly or simultaneously, on trehalose accumulation and survival of isolates of $S$. cerevisiae and S. boulardii.

\begin{tabular}{|c|c|c|c|}
\hline \multirow[t]{2}{*}{ Strain } & \multirow[t]{2}{*}{$\begin{array}{l}\text { Baseline trehalose } \\
\text { ( } \mu \text { moles glucose } \\
\mathrm{g}^{-1} \text { wet weight) } \\
\text { contents }^{1} /(\%)\end{array}$} & \multicolumn{2}{|c|}{$\begin{array}{l}\text { Alteration of trehalose } \\
\text { content induced by stress } \\
\text { (x fold in relation to baseline } \\
\text { contents) / Survival }(\%)\end{array}$} \\
\hline & & $\begin{array}{l}\text { Pancreatic } \\
\text { juice }^{2}\end{array}$ & $\begin{array}{l}\text { Pancreatic juice } \\
+ \text { mild heat }^{3}\end{array}$ \\
\hline S. boulardii & $0.20 \pm 0.18 / 100$ & $94.1 * / 36$ & $160.2 * / 21$ \\
\hline UFMG20 & $2.11 \pm 1$ & $16.7 * / 42$ & $18.4 * / 33$ \\
\hline UFMG 21 & $0.74 \pm 0.48 / 100$ & $4.5^{*} / 38$ & $28.4 * * / 41$ \\
\hline UFMG 22 & $1.96 \pm 1.14 / 100$ & $23.0 * / 53$ & $33.3 * / 51$ \\
\hline UFMG 23 & $0.95 \pm 0.85 / 100$ & $2.9 / 49$ & $19.2 * * / 37$ \\
\hline UFMG 24 & $5.03 \pm 2.92 / 100$ & $6.6 * / 40$ & $9.9 * / 27$ \\
\hline
\end{tabular}

${ }^{1} \mathrm{YPG}, 30^{\circ} \mathrm{C} .{ }^{2}$ Pancreatin $1.0 \mathrm{gl}^{-1}, 30^{\circ} \mathrm{C}, \mathrm{pH} 8.0,2.0 \%$ glucose. ${ }^{3}$ Pancreatin $1.0 \mathrm{gl}^{-1}, 37^{\circ} \mathrm{C}, \mathrm{pH} 8.0,2.0 \%$ glucose. ${ }^{*}$ Significant difference from baseline levels. **Significant difference from pancreatin stress levels alone.

particularly those with recurrent Clostridium difficileassociated diseases (22). Taxonomically, recent studies of mitochondrial DNA showed that $S$. boulardii is part of the Saccharomyces sensu stricto complex, being closely related to S. cerevisiae (13) and form a separate cluster located within the species (17). Other Saccharomyces spp. or members of other yeast genera may have probiotic activity similar to that of $S$. boulardii or even better, as already demonstrated by Martins et al. $(14,15)$ in mice models. The objective of this work was to determine whether higher trehalose levels or the capacity to produce large amounts of this sugar were advantageous to microbial survival in in vitro experiments simulating different stress conditions commonly present in the

Table 4. Yeast counts (in $\log \mathrm{cfu} \mathrm{g}^{-1}$ of feces \pm SD) during ten days in the feces of gnotobiotic mice after a single intragastric inoculum of $10^{8}$ viable cells.

\begin{tabular}{ccccc}
\hline Strain & \multicolumn{4}{c}{ Time (days) } \\
\cline { 2 - 5 } & 1 & 4 & 7 & 10 \\
\hline S. boulardii & $7.20 \pm 0.25$ & $4.29 \pm 0.13$ & $4.23 \pm 1.00$ & $3.74 \pm 0.37$ \\
UFMG20 & 0 & 0 & 0 & 0 \\
UFMG21 & $5.83 \pm 0.56$ & $5.29 \pm 0.94$ & $5.29 \pm 0.94$ & $5.18 \pm 0.34$ \\
UFMG22 & 0 & 0 & 0 & 0 \\
UFMG23 & $6.76 \pm 0.29$ & $4.83 \pm 0.60$ & $5.33 \pm 0.33$ & $5.33 \pm 0.33$ \\
UFMG24 & $6.92 \pm 0.14$ & $5.26 \pm 0.37$ & $6.11 \pm 0.41$ & $5.86 \pm 0.09$ \\
\hline
\end{tabular}


gastrointestinal tract and if these results can be extrapolated to in vivo situation.

High initial levels of trehalose (UFMG 20, UFMG 22 and UFMG 24) or the capacity to induce high trehalose production (S. boulardii) seem to be involved partially in an improved cell survival at pH 2.0 and mild heat shock. Significant numbers of S. cerevisiae cells survived exposure to $2 \mathrm{mg} \mathrm{ml}^{-1}$ of bile salts (Table 2) but induction of trehalose synthesis was observed for only two strains (UFMG 20 and UFMG 21). On the other hand, $S$. boulardii showed extreme sensitivity to bile salts and its cells were unable to survive this treatment. Determination of the susceptibility of microorganisms to bile salts is a very important step in the selection of intestinal probiotics. Bile stress for ingested microorganisms is complex because concentrations and persistence times vary along the various portions of the small intestine. The mechanism of tolerance is not fully understood and the minimum acceptable level of bile tolerance for a candidate probiotic also remains unknown (12). Conditions that simulated the small intestine at physiological temperature (Table 3) were aggressive to yeast cells, as confirmed by survival rates. Induction of trehalose synthesis by yeast cells was similar to that observed after exposure to simulated gastric juice. However, these increased trehalose levels in $S$. boulardii were not associated with high survival, as observed under acidic conditions.

The results of the present study confirm that the conditions present in the gastrointestinal tract are very aggressive for yeast cells and induce trehalose biosynthesis. However, direct correlation between yeast survival and trehalose levels after exposure to stress conditions was not always found. This lack of correlation has been also observed by other authors (2). The results also showed that only after exposure to bile salts the $S$. cerevisiae isolates withstood stress conditions better than $S$. boulardii. Additionally, the initial cellular levels of trehalose were higher in the former than in the commercialized yeast. Despite of the fact that in vitro test of the five strains showed very good performance; there was no absolute correlation with the colonization of the gastrointestinal tract of gnotobiotic animals. We concluded that the favorable results obtained in vitro were not always confirmed under in vivo conditions.

As one of the largest, most biodiverse countries in the world, Brazil may provide a rich source of microorganisms for potential probiotic use. In the present study, yeast strains isolated from Brazilian Atlantic rain forest were tested as possible biotherapeutic for intestinal infections. Yeasts identified as $S$. cerevisiae were selected because they are already known to be relatively safe microorganisms that are genetically very close to $S$. boulardii. Once $S$. boulardii was isolated from lychee fruit, we have searched some ambiental yeasts for probiotic use and we have searched them among the S. cerevisiae species for their non pathogenic capacity and for their taxonomic similarity with $S$. boulardii.

\section{ACKNOWLEDGEMENTS}

This study was supported grants from the Fundação de Amparo à Pesquisa do Estado de Minas Gerais (FAPEMIG) and CNEN/CDTN.

\section{RESUMO}

\section{Efeito da trealose na seleção de leveduras para uso como probióticos utilizando testes in vitro e in vivo}

Probióticos são definidos como microrganismos (bactérias e leveduras) que exercem um efeito benéfico na saúde do hospedeiro quando ingeridos em quantidades adequadas. A seleção desses agentes bioterapêuticos normalmente é feita por testes in vitro simulando o ambiente gastrointestinal que determina a capacidade de sobrevivência no trato digestivo. Neste trabalho, a possibilidade de extrapolação dos dados obtidos nos testes in vitro para as condições in vivo foi estudada utilizando cinco linhagens de Saccharomyces cerevisiae isoladas da floresta Atlântica brasileira. O conteúdo de trealose e a sobrevivência após a exposição a diversos estresses fisiológicos geralmente encontrados no trato gastrointestinal de humanos foram determinados para as cinco linhagens e os resultados comparados com a Saccharomyces boulardii, um probiótico conhecido. Esses resultados foram completados com a capacidade de colonização do trato gastrointestinal de camundongos gnotobióticos pelas leveduras. Pelos resultados obtidos, concluimos que os testes in vitro não são confirmados pelos ensaios in vivo, indicando que essa extrapolação não pode sempre ser feita.

Palavras-chave: Probiótico, Saccharomyces boulardii, Saccharomyces cerevisiae, estresse, trealose.

\section{REFERENCES}

1. Agarwal, N.; Kamra, D.N.; Chaudhary, L.C.; Sahoo, A.; Pathak, N.N. (2000). Selection of Saccharomyces cerevisiae strains for use as a microbial feed additive. Lett. Appl. Microbiol., 31, 270-273.

2. Alexandre, H.; Plourde, L.; Charpentier, C.; François, J. (1998). Lack of correlation between trehalose accumulation, cell viability and intracellular acidification as induced by various stresses in Saccharomyces cerevisiae. Microbiology, 144, 1103-1111.

3. Attfield, P.V. (1987). Trehalose accumulates in Saccharomyces cerevisiae during exposure to agents that induce the heat shock response. FEBS Lett., 225, 259-263.

4. Bengmark, S. (1998). Ecological control of the gastrointestinal tract. The role of probiotic flora. Gut, 42, 2-7.

5. Berg, R.D. (1998). Probiotics, prebiotics or 'conbiotics'. Trends Microbiol., 6, 89-92.

6. Brandão, R.L.; Castro, I.M.; Bambirra, E.A.; Amaral, S.C.; Fietto, L.G.; Tropia, M.J.; Neves, M.J.; Dos Santos, R.G.; Gomes, N.C.; Nicoli, J.R. (1998). Intracellular signal triggered by cholera toxin in Saccharomyces boulardii and Saccharomyces cerevisiae. Appl. Environ. Microbiol., 64, 564-568. 
7. Charteris, W.P.; Kelly, P.M.; Morelli, L.; Collins, J.K. (1998). Development and application of an in vitro methodology to determine the transit tolerance of potentially probiotic Lactobacillus and Bifidobacterium species in the upper human gastrointestinal tract. J. Appl. Microbiol., 84, 759-768.

8. Czerucka, D.; Rampal, P. (2002). Experimental effects of Saccharomyces boulardii on diarrheal pathogens. Microbes Infect., 4, 733-739.

9. Hottiger, T.; Boller, T.; Wiemken, A. (1987). Rapid changes of heat and dessication tolerance correlated with changes of trehalose content in Saccharomyces cerevisiae cells subjected to temperatures shifts. FEBS Lett., 220, 113-115.

10. Klaenhammer, T.R.; Kullen, M.J. (1999). Selection and design of probiotics. Int. J. Food Microbiol., 50, 45-57.

11. Kurtzman, C.P.; Fell, J.W. (1998). The Yeast: a Taxonomic Study. $4^{\text {th }}$ edn. Amsterdam, Elsevier Science.

12. Marteau, P.; Minekus, M.; Harvenaar, R.; Huis in't Veld, J.H. (1997). Survival of lactic bacteria in a dynamic model of the stomach and small intestine: validation and the effects of bile. J. Dairy Sci., 80, 1031-1037.

13. Mallié, M.; Nguyen, Van P.; Bertout, S.; Vaillant, C.; Bastide, J. (2001). Genotypic study of Saccharomyces boulardii compared to the Saccharomyces sensu stricto complex species. J. Mycol. Med., $11,19-25$

14. Martins, F.S.; Nardi, R.M.D.; Arantes, R.M.E.; Rosa, C.A.; Neves, M.J.; Nicoli, J.R. (2005). Screening of yeast as probiotic based on capacities to colonize the gastrointestinal tract and to protect against enteropathogen challenge in mice. J. Gen. Appl. Microbiol., 51, 83 92.

15. Martins, F.S.; Rodrigues, A.C.P.; Tiago, F.C.P.; Penna, F.J.; Rosa, C.A.; Arantes, R.M.; Nardi, R.M.; Neves, M.J.; Nicoli, J.R. (2007).
Saccharomyces cerevisiae strain 905 reduces the translocation of Salmonella enterica serotype Typhimurium and stimulates the immune system in gnotobiotic and conventional mice. J. Med. Microbiol., 56, 352-359.

16. Mitterdorfer, G.; Kneifel, W.; Viernstein, H. (2001). Utilization of prebiotic carbohydrates by yeasts of therapeutic relevance. Lett. Appl. Microbiol., 33, 251-255.

17. Mitterdorfer, G.; Mayer, H.K.; Kneifel, W.; Viernstein, H. (2002). Clustering of Saccharomyces boulardii strains within the species Saccharomyces cerevisiae using molecular typing techniques. J. Appl. Microbiol., 93, 521-530.

18. National Research Council. (1996). Guide for the Care and Use of Laboratory Animals. Washington, D.C., National Academy Press.

19. Neves, M.J.; Terenzi, H.F.; Leone, F.A.; Jorge, J.A. (1994). Quantification of trehalose in biological samples with a conidial trehalase from the thermophilic fungus Humicola grisea var. thermoidea. World J. Microbiol. Biotechnol., 10, 17-19.

20. Rodrigues, A.C.P.; Nardi, R.M.; Bambirra, E.A.; Vieira, E.C.; Nicoli, J.R. (1996). Effect of Saccharomyces boulardii against experimental oral infection with Salmonella typhimurium and Shigella flexneri in conventional and gnotobiotic mice. J. Appl. Bacteriol., 81, 251256.

21. Singer, M.A.; Lindquist, S. (1998). Thermotolerance in Saccharomyces cerevisiae: the yin and yang of trehalose. Trends Biotechnol., 16, 460-468.

22. Surawicz, C.M.; McFarland, L.V.; Greenberg, R.N.; Rubin, M.; Fekety, R.; Mulligan, M.E.; Garcia, R.J.; Brandmarker, S.; Bowen, K.; Borjal, D.; Elmer, G.W. (2000). The search for a better treatment for recurrent Clostridium difficile disease: use of high-dose vancomycin combined with Saccharomyces boulardii. Clin. Infect. Dis., 31, 10121017. 